\title{
Analisis Wacana Kritis Kasus Penyerangan Terhadap Jemaah Ahmadiyah di Cikeusik
}

\author{
Wulan Purnama Sari \\ Fakultas Ilmu Komunikasi Universitas Tarumanagara \\ wulanp@ fikom.untar.ac.id
}

\begin{abstract}
This paper examines the phenomenon of Ahmadiyah congregation in Indonesia which has long been a conversation for many years. Ahmadiyah congregation phenomenon raised in this paper is the result of news from Kompas Online media, in the case of attack in Cikeusik in 2011 ago. The method used is critical discourse analysis from Theo Van Leeuwen, who sees the representation of social actors and activities displayed in a text. The representation of the actor and the social act is shown through exclusion and inclusion. The main news that became the object of analysis is the news published by Kompas Online on February 06, 2011, entitled "Thousands of Citizens Cikeusik Serang Jemaah Ahmadiyah". This study examines the use of language on the news to find what discourse is trying to be produced through the news. This study also aims to know the constellation of power in the news, how the representation of Ahmadiyah congregation groups in the news. As a result it is known that the Ahmadiyya congregation group is described as a marginal group, there is an unequal power relationship between the minority and the majority. The Ahmadiyya congregation is unfairly displayed in the discourse or in other words there is discrimination against the Ahmadiyya congregation. It is hoped that this publication will make all Indonesian people become aware of the existence of discrimination and can be critical in facing it, especially in understanding the news about a particular case in mass media.
\end{abstract}

Keywords: ahmadiyah, critical discourse analysis, discrimination

\begin{abstract}
Abstrak
Tulisan ini mengkaji fenomena jemaah Ahmadiyah di Indonesia yang telah lama menjadi perbincangan selama bertahun - tahun. Fenomena jemaah Ahmadiyah yang diangkat pada tulisan ini merupakan hasil pemberitaan dari media Kompas Online, pada kasus penyerangan di Cikeusik tahun 2011 silam. Metode yang digunakan adalah analisis wacana kritis dari Theo Van Leeuwen, yang melihat representasi aktor sosial dan kegiatan ditampilkan dalam suatu teks. Representasi aktor dan tindakan sosial tersebut ditampilkan melalui eksklusi dan inklusi. Berita utama yang menjadi objek analisis adalah berita yang diterbitkan oleh Kompas Online pada 06 Februari 2011, dengan judul "Seribuan Warga Cikeusik Serang Jemaah Ahmadiyah". Penelitian ini mengkaji penggunaan bahasa pada berita tersebut untuk mencari wacana apa yang berusaha diproduksi melalui berita tersebut. Penelitian ini juga bertujuan untuk mengetahui konstelasi kekuatan dalam berita tersebut, bagaimana representasi kelompok jemaah Ahmadiyah dalam berita tersebut. Sebagai hasilnya diketahui bahwa kelompok jemaah Ahmadiyah digambarkan sebagai kelompok marginal, terdapat hubungan kekuasaan yang tidak imbang antara kelompok minoritas dengan kelompok mayoritas. Kelompok jemaah Ahmadiyah ditampilkan secara tidak adil dalam wacana tersebut atau dengan kata lain terdapat diskriminasi terhadap jemaah Ahmadiyah. Diharapkan dengan adanya
\end{abstract}


pemberitaan ini menjadikan seluruh masyarakat Indonesia menjadi sadar akan adanya tindak diskriminasi dan dapat bersikap secara kritis dalam menghadapinya, teruatama dalam memahami pemberitaan tentang suatu kasus tertentu di media massa.

Kata Kunci: ahmadiyah, analisis wacana kritis, diskriminasi

\section{Pendahuluan}

Fenomena kasus Ahmadiyah di Indonesia telah lama menjadi perbincangan. Perbincangan mengenai Ahmadiyah ini kembali menjadi mencuat ketika diberitakan terjadi penyerangan atas warga Ahmadiyah di Cikeusik, Pandeglang, Banten, pada Minggu (6/2/2011). Berita tersebut menjadi sorotan selama beberapa waktu di berbagai media. Salah satunya adalah di media Kompas Online yang memberitakan peristiwa tersebut mulai dari bulan Februari 2011 sampai dengan sekitar bulan Juli 2011. Salah satu berita yang dimuat oleh kompas yang berjudul "Seribuan Warga Cikeusik Serang Jemaah Ahmadiyah" yang dimuat pada tanggal 6 Februari 2011. Berita tersebut menuliskan bahwa terjadi penyerangan atas Jemaah Ahmadiyah di Cikeusik oleh sekitar 1000 warga, yang dipicu karena kedatangan jemaah Ahmadiyah dari luar daerah. Akibat kejadian itu, satu kendaraan roda empat dibakar masa, satu unit dimasukan ke dalam jurang, dan satu unit rumah dirusak. (Wadrianto, 2011).

Kasus penyerangan atau bentrokan yang melibatkan jemaah Ahmadiyah telah sejak lama terjadi. Salah satu peristiwa yang belum terjadi diberitakan pada tahun 2016 kemarin. Pada 25 Juni 2016 Kompas Online mengeluarkan berita dengan judul "Tak Melakukan Kekerasan, Mengapa Ahmadiyah Dimusuhi?". Berita ini menuliskan bahwa kelompok atau jemaat Ahmadiyah seringkali mengalami diskriminasi, baik dari masyarakat hingga penegak hukum. Masjidmasid Ahmadiyah disegel hingga dirusak di sejumlah daerah. Penganut aliran Ahmadiyah dilarang untuk beribadah. Padahal, kata Zuhairi, Ahmadiyah merupakan aliran Islam yang membawa kedamaian dan menjauhi cara-cara kekerasan. (Ishanuddin, 2016).

Berdasarkan sejarah ajarah Ahmadiyah telah masuk ke Indonesia sejak tahun 1920-an dan selama hamper seabad tidak mengalami konflik kekerasan dengan kelompok lain. Pada zaman penjajahan, aliran ini mendapat dukungan dari Pemerintah Belanda. Pada era pemerintahan Soekarno dan Soeharto boleh dikatakan tidak ada penyerangan fisik terhadap penganut Ahmadiyah. Reaksi yang cukup keras muncul kemudian dari aliran kalangan NU dan Muhammadiyah. Kelompok Ahmadiyah ini dituntut untuk menyatakan diri sebagai bukan bagian dari agama Islam atau menuntut agar semua warga Ahmadiyah berpindah agama. Aliran Ahmadiyah dan aliran Islam lainnya, seperti NU dan Muhammadiyah memiliki perbedaan dalam beberapa ajaran, seperti misalnya ajaran mengenai mati jihad. (Adam, 2011)

Perbedaan paham mengenai ajaran agama ini menjadikan aliran Ahmadiyah dan aliran lainnya menjadi berselisih, sehingga pada akhirnya muncul konflik diantara aliran-aliran yang berbeda paham ini. Dalam konflik yang terjadi seringkali yang menjadi korban adalah warga atau jemaah Ahmadiyah, mulai dari 
bentrokan sampai dengan penghancuran sarana dan prasarana. Perbedaan ini kemudian semakin bertambah buruk ketika masyarakat lainnya diluar kelompok atau jemaat Ahmadiyah menolak keberadaan kelompok atau jemaah Ahmadiyah dan menganggap aliran Ahmadiyah sebagai aliran agama sesat.

Penelitian ini bertujuan untuk mengetahui bagaimana jemaah Ahmadiyah (aktor) dan kasus penyerangan di Cikeusik (tindakan) ditampilkan dalam teks, khususnya dalam berita di Kompas Online dnegan tajuk "Seribuan Warga Cikeusik Serang Jemaah Ahmadiyah". Wacana seperti apa yang ditampilkan berita tersebut terhadap aktor dan tindakan sosial ini, sehingga teknik analisis yang digunakan adalah analisis wacana kritis.

Penelitian dengan menggunakan analisis wacana kritis bukanlah suatu hal baru. Salah satu penelitian terdahulu dilakukan oleh Tanjung (2015) yang menggunakan teknik analisis wacana kritis dari Fairclough untuk meneliti representasi orang baik dalam pidato yang dilakukan oleh Anies Baswedan mengenai “Anies Baswedan's Great Speech, Mengapa Jokowi”. Hasil penelitian menunjukkan bahwa Anies Baswedan mencoba melakukan generalisasi konsep orang baik. Pada saat yang bersamaan kemudian mengaburkan varian makna dari orang baik itu sendiri. Anies berupaya menggiring makna orang baik terhadap dirinya dengan menggunakan pemikiran silogisme pada pidatonya, dimana jika masyarakat setuju Jokowi merupakan orang baik maka dirinya adalah orang baik pula.

Analisis wacana kritis yang digunakan adalah analisis wacana kritis dari Theo Van Leeuwen. Pendekatan utama dari Theo Van Leeuwen adalah mendeteksi bagaimana aktor sosial (orang, kelompok, organisasi, dsb) dan kegiatan (tindakan, perilaku, dsb) ditampilkan dalam suatu teks. Menurut Van Leeuwen melalui wacana aktor dan perilaku sosial kerap kali termarjinalkan. Aktor sosial yang kebetulan tidak dominan ditampilkan secara tidak adil dalam wacana. Representasi aktor dan tindakan sosial tersebut, ditampilkan lewat eksklusi dan inklusi. Eksklusi merupakan proses bagaimana aktor sosial ditampilkan. Sedangkan inklusi merupakan bagaimana masing-masing aktor sosial ditampilkan lewat teks. (Eriyanto,2001)

\section{Metode Penelitian}

Metode yang digunakan dalam penelitian ini adalah analisis wacana kritis dari Theo Van Leeuwen, yang berupaya mendeteksi bagaimana aktor dan kegiatan sosial ditampilkan dalam suatu teks media. Analisis dilakukan dengan melihat proses eksklusi dan inklusi yang terdapat dalam teks media. Kemudian objek penelitian adalah peristiwa penyerangan terhadap jemaah Ahmadiyah di Cikeusik, sedangkan subjek penelitian adalah berita mengenai peristiwa tersebut yang terdapat dalam media Kompas Online pada tanggal 06 Februari 2011 dengan judul "Seribuan Warga Cikeusik Serang Jemaah Ahmadiyah". 


\section{Hasil Penemuan Dan Diskusi}

Proses analisis wacana kritis Theo Van Leeuwen dimulai dengan melihat proses eksklusi dan inklusi yang terdapat dalam teks media. Eksklusi merupakan proses tentang bagaimana aktor sosial ditampilkan. Sedangkan inklusi merupakan bagaimana masing-masing aktor sosial ditampilkan lewat teks. Kedua proses ini dilakukan lewat strategi wacana, dengan memakai kata, kalimat, susunan kalimat tertentu, cara bercerita, dsb. Proses eksklusi dapat dilihat dari adanya pasivasi, nominalisasi, penggantiaan anak kalimat. Proses inklusi dilakukan dengan melihat diferensiasi-indeferensiasi, objektivasi-abstraksi, nominasi-kategorisasi, nominasiidentifikasi, determinasi-indeterminasi, asimilasi-individualisasi, asosiasidisosiasi. (Eriyanto, 2001)

Pada proses eksklusi di teks media tersebut dapat dilihat bahwa tidak terdapat pasivasi, nominalisasi, dan penggantiaan anak kalimat. Aktor atau jemaah Ahmadiyah ditampilkan dengan jelas, bahkan aktor lainnya yang terlibat dalam teks tersebut warga Cikeusik juga ditampilkan dalam teks media. Sebagai contoh dalam kalimat berikut ini, "Sekitar seribuan warga Kecamatan Cikeusik, Kabupaten Pandeglang, Provinsi Banten, menyerang Jemaah Ahmadiyah di Desa Umbulan setempat", dalam kalimat tersebut dapat dilihat bahwa aktor warga Cikeusik dan jemaah Ahmadiyah ditampilkan secara jelas melalui kalimat aktif. Kesimpulannya dapat diketahui bahwa dalam teks media tersebut tidak ada aktor yang disembunyikan atau dihilangkan, sehingga berarti tidak terdapat strategi wacana yang dilakukan untuk menyembunyikan atau menghilangkan suatu aktor tertentu.

Pada proses inklusi merujuk kepada bagaimana aktor ditampilkan dalam teks. Kemudian bila melihat teks secara menyuluruh dapat diketahui bahwa strategi inklusi yang terdapat dalam teks ini bersifat objektivasi-abstraksi dan determinasi dan indeterminasi. Strategi objektivasi-abstraksi terlihat dalam kalimat, "Sekitar seribuan warga Kecamatan Cikeusik, Kabupaten Pandeglang, Provinsi Banten, menyerang Jemaah Ahmadiyah di Desa Umbulan setempat, Minggu (6/2/2011) sekitar pukul 10.30 WIB". Pada kalimat tersebut dapat dilihat bahwa aktor sosial ditampilkan dengan tidak memberi petunjuk secara konkrit atau ditampilkan dalam bentuk abstraksi, kata seribuan warga menggambarkan aktor sosial yaitu warga tidak secara jelas. Hal ini menandakan bahwa aktor sosial yang dalam hal ini melakukan penyerangan atau tindakan buruk digambarkan melalui abstraksi. Eriyanto (2001) menjelaskan bahwa aktor atau tindakan sosial yang buruk, umumnya dilakukan dengan menggunakan strategi wacana berupa abstraksi.

Strategi determinasi-indeterminasi melihat apakah aktor sosial dirujuk atau disebut secara jelas atau anonym, karena hal ini menimbulkan kesan dan makna yang diterima oleh khalayak menjadi berbeda. Pada teks berita yang diteliti ini, wacana yang muncul adalah adanya determinasi. Pada kalimat "Seribuan Warga Cikeusik Serang Jemaah Ahmadiyah", dapat dilihat bahwa aktor sosial atau warga tidak disebut secara jelas. Kata warga sendiri merupakan generalisasi yang menunjukkan bahwa peristiwa penyerangan terjadi dalam skala yang sangat luas. 
Wulan Purnama Sari : Analisis Wacana Kritis Kasus Penyerangan Terhadap Jemaah Ahmadiyah di Cikeusik

Berdasarkan penjelasan diatas dapat disimpulkan bahwa pada proses inklusi aktor sosial yang tampil dalam teks, warga dan jemaah Ahmadiyah ditampilkan secara berbeda dalam teks. Aktor sosial, warga, ditampilkan secara abstrak dan determinasi, atau dengan kata lain ditampilkan secara tidak jelas dan digeneralisasi. Hal ini dikarenakan aktor sosial, warga, merupakan aktor sosial yang melakukan tindakan penyerangan atau tindakan yang buruk.

Hasil analisis wacana kritis terhadap teks media ini menunjukkan bahwa terdapat dua aktor sosial yang muncul, yaitu warga dan jemaah Ahmadiyah. Sedangkan kegiatan sosial yang tampil dalam teks adalah penyerangan yang dilakukan warga kepada jemaah Ahmadiyah. Anilisis dalam proses eksklusi menunjukkan bahwa tidak ada aktor sosial yang dihilangkan atau disembunyikan dalam teks. Kemudian pada tahap inklusi kedua aktor sosial tersebut ditampilkan secara berbeda dalam teks. Dimana aktor sosial warga ditampilkan secara tidak jelas melalui strategi abstraksi dan generalisasi.

Hasil dari analisis wacana kritis menunjukkan bahwa terdapat diskriminasi yang tergambar melalui teks media yang dianalisis, dimana jemaah Ahmadiyah menjadi korban diskriminasi. Diskriminasi ini merupakan kelanjutan dari konflik yang berkepanjangan antara jemaah Ahmadiyah dengan jemaah lainnya yang berada diluar aliran Ahmadiyah. Pemahaman lebih lanjut mengenai konflik Ahmadiyah ini harus dimulai dari pemahaman tentang agama sebagai cara pandang dan kaitannya dengan budaya. Keluarga, komunitas (negara), dan cara pandang (agama) merupakan tiga penanda awal evolusi dari sesuatu yang disebut sebagai budaya. Tiga organisasi sosial ini bekerja sama dalam meneruskan kepercayaan yang paling penting dari suatu budaya. Pada kali ini yang akan dibahas lebih mendalam adalah cara pandang yang erat kaitannya dengan agama. Ishii, Cooke, dan Kloph menyatakan bahwa cara pandang merupakan orientasi budaya terhadap Tuhan, kemanusiaan, alam, pertanyaan tentang keberadaan sesuatu, alam dan kosmos, kehidupan, moral, dan alasan etis, penderitaan, kematian, dan isu filosofis lainnya yang mempengaruhi bagaimana anggotanya memandang dunia (Samovar, Porter \& McDaniel, 2010). Berdasarkan definisi tersebut dapat disimpulkan bahwa cara pandang adalah cara atau metode yang digunakan untuk melihat gambaran mengenai dunia dan tentang peran yang dimiliki setiap manusia dalam dunia tersebut.

Samovar, Porter \& McDaniel (2010) menyatakan bahwa cara pandang tiap individu berasal dari budaya, dikirimkan melalui banyak saluran, terdiri atas banyak elemen dan terwujud dalam berbagai bentuk, yang salah satunya adalah agama. Kata agama berasal dari bahasa latin religere yang berarti untuk mengikat. Hal ini menunjukkan bahwa agama mengikat manusia dengan hal - hal yang sakral. Sejarah menunjukkan bahwa agama telah ada bersama - sama dalam memelihara cara pandang budaya. Agama menjadi penyedia nilai - nilai yang dianut dan mengatur pengikutnya. Nilai - nilai yang ada dalam agama tidak hanya menjadi pedoman hidup tapi merupakan hidup itu sendiri yang dilakukan dalam kegiatan sehari - hari.

Bagi penganut Ahmadiyah ajaran agamanya merupakan kebenaran yang diyakini, yang pada akhirnya membentuk identitas agama penganutnya. Identitas agama dapat didefinisikan sebagai rasa memiliki kepada suatu kelompok agama 
tertentu (Martin\&Nakayama, 2007). Perbedaan identitas agama ini kemudian membentuk kelompok - kelompok yang anggotanya didasarkan pada persamaan kepercayaan akan suatu agama tertentu. Dimana dilihat berdasarkan kasus ini ada dua identitas agama yang terlibat konflik, yaitu kelompok umat Islam pada umumnya dengan kelompok jemaah Ahmadiyah, yang kemudian masing masing kelompok memiliki stereotip, prasangka, dan diskriminasi terhadap satu sama lain.

Samovar, Porter, dan McDaniel (2010) menyatakan bahwa pengelompokkan individu berdasarkan perbedaan identitasnya, dalam hal ini adalah identitas agama, dapat melahirkan sisi gelap dari identitas yaitu munculnya stereotip, prasangka, dan diskriminasi. Sekarang untuk memahami kasus konflik jemaah Ahmadiyah ini lebih lanjut akan dibahas terlebih dahulu mengenai definisi dari stereotip, prasangka, dan diskriminasi.

Lipman (1922) seperti dikutip dalam Gudykunts dan Kim (2003) merujuk stereotip sebagai sebuah gambaran di dalam kepala seseorang mengenai orang lain. Saat seseorang bertemu dengan orang lain secara tidak sadar maupun sadar orang tersebut mulai melakukan pengkategorisasian atau pengklasifikasian berdasarkan tanda fisik yang ada, seperti warna kulit, ukuran tubuh, etnis, dll. Stereotip ini dapat bersifat negatif dan positif, tetapi apapun sifatnya keduanya dapat berdampak buruk karena menciptakan realitas tidak nyata dan sekali stereotip ada sulit untuk dihilangkan. Sedangkan istilah prasangka berasal dari bahasa latin praejudicium yang berarti penghakiman berdasarkan pada keputusan atau pengalaman sebelumnya. Dimana pengertian lengkap prasangka merupakan generalisasi kaku dan menyakitkan mengenai sekelompok orang, menyakitkan dalam arti bahwa orang memiliki sikap yang tidak fleksibel yang didasarkan atas sedikit atau tidak ada bukti sama sekali (Samovar, 2010).

Kemudian prasangka dinyatakan dalam berbagai cara. Allport, seperti dikutip dalam Samovar (2010) menyatakan lima pernyataan prasangka, yaitu sebagai berikut: (1) Pertama, prasangka dapat dinyatakan melalui antikolusi, yaitu istilah negatif atau stereotip mengenai anggota dari kelompok target; (2) orang memiliki prasangka ketika menghindari dan/atau menarik diri untuk berhubungan dengan kelompok yang tidak disukai; (3) prasangka menghasilkan diskriminasi, dan orang yang menjadi target prasangka akan berusaha untuk keluar dari kelompoknya pekerjaan, tempat tinggal, hak politik, gereja, dll menjadi dipermasalahkan; (4) ketika prasangka berpindah ke level berikutnya, yaitu ekspresi. Disini prasangka akan berubah menjadi bentuk serangan fisik; (5) extermination atau pembasmian. Prasangka seperti ini mengarah pada tindakan kekerasan fisik terhadap kelompok luar. Beradasarkan penjelasan tersebut dapat disimpulkan bahwa diskriminasi termasuk salah satu bentuk dalam pernyataan prasangka. Sehingga dapat diakatakan bahwa diskriminasi adalah perilaku yang merupakan hasil dari prasangka yang juga tidak terlepas dari stereotip. Diskriminasi ini menyebabkan orang ditolak partisipasi atau ditolak hak-nya berdasarkan pada keanggotaan kelompok budaya, seperti ras, gender, agama, dll.

Munurut Samovar, Porter, dan McDaniel (2010) salah satu fungsi umum dari prasangka adalah menyatakan nilai, dimana fungsi ini dapat dilihat ketika orang - orang percaya bahwa perilakunya menunjukkan nilai tertinggi dan paling 
bermoral dari semua budaya, bahwa hanya ada satu Tuhan yang benar yaitu Tuhan yang mereka percayai. Berdasarkan penjelasan ini dapat ditarik kesimpulan bahwa prasangka yang dimiliki kelompok mayoritas (diluar kelompok Ahmadiyah) berfungsi untuk menyatakan nilai, kelompok mayoritas ini percaya bahwa nilai KeTuhanan berbeda yang dimiliki jemaah Ahmadiyah adalah salah dan kerenanya tindakan diskriminasi dalam wujud penyerangan fisik maupun tidak terhadap kelompok Ahmadiyah merupakan suatu kebenaran.

Berdasarkan pemahaman diatas mengenai stereotip, prasangka, dan diskriminasi. Konflik dalam kasus ini terjadi akibat adanya perbedaan identitas agama antara kelompok mayoritas dengan kelompok jemaah Ahmadiyah. Perbedaan nilai budaya yang dimiliki tiap identitas saling bersinggungan dalam kehidupan sosial sehari - hari. Permasalahan muncul ketika salah satu kelompok tidak dapat menerima adanya perbedaan tersebut. Kelompok mayoritas kemudian memiliki stereotip dan prasangka negatif mengenai keberadaan jemaah Ahmadiyah di lingkungan tempat tinggalnya. Diskriminasi sebagai bentuk pernyataan prasangka dapat dilihat, misalnya dari aksi ribuan warga Cikeusik yang melakukan penyerangan kepada jamaah Ahmadiyah,

McQuail (2010) menjabarkan tentang fungsi media dalam masyarakat, yaitu: penyedia informasi yang menjelaskan hubungan dan kontinuitas, menyediakan hiburan, dan sebagai alat mobilisasi. Terkait mengenai berita di Kompas Online yang menjadi subjek penelitian dapat dilihat bahwa Kompas Online telah menjalakan fungsinya sebagai penyedia informasi. Kompas Online menyediakan informasi pada masyarakat mengenai peristiwa terhadap jemaah Ahmadiyah di Indonesia, walaupun berdasakan berita yang dianalisis terdapat aktor sosial yang tidak ditampilkan secara jelas. Sebagai masyarakat pada era modern seperti sekarang ini, sudah sewajarnya bila setiap anggota masyarakat memiliki sikap yang kritis terkait dengan segala hal, termasuk didalamnya mengenai jemaah Ahmadiyah ini.

\section{Simpulan}

Berdasarkan uraian dan pembahasan diatas dapat disimpulkan bahwa melalui analisis wacana kritis pada berita di Kompas Online pada 06 Februari 2011 diketahui terdapat dua aktor dalam teks media tersebut, dan tidak ada aktor yang dihilangkan atau disembunyikan. Walaupun, salah satu aktor sosial ditampilkan tidak secara jelas melalui abstraksi dan determinasi. Kesimpulan aktor sosial, jemaah Ahmadiyah, dimarginalkan karena tidak terdapat perlakuan yang sama dengan aktor sosial lainnya, dengan kata lain terdapat diskriminasi pada jemaah Ahmadiyah. Penyebab terjadinya diskriminasi ini adalah karenanya adanya perbedaan cara pandang mengenai agama Islam yang dimiliki kedua kelompok. Kemudian perbedaan cara pandang ini menjadikan identitas agama yang dimiliki tiap kelompok juga berbeda. Adanya perbedaan identitas melahirkan stereotip, prasangka, dan diskriminasi antar kelompok. Dimana kelompok yang kuat atau mayoritas akan menindas kelompok yang lemah atau minoritas. 
Terjadinya diskriminasi atas jemaah Ahmadiyah ini juga telah disuarakan oleh media, salah satunya adalah media Kompas Online yang melalui pemberitaannya menyediakan informasi bahwa telah terjadi diskriminasi terhadap kelompok atau jemaah Ahmadiyah. Diharapkan dengan adanya pemberitaan ini menjadikan seluruh masyarakat Indonesia menjadi sadar akan adanya tindak diskriminasi dan dapat bersikap secara kritis dalam menghadapinya.

Selanjutnya, penulis memberikan saran bahwa dapat dilakukan penelitian yang lebih mendalam untuk mengkaji fenomena jemaah Ahmadiyah di Indonesia. Penelitian dapat dilakukan secara kualitatif maupun kuantitatif dengan berbagai perspektif yang juga sesuai dengan perspektif ilmu komunikasi secara keseluruhan.

\section{Ucapan Terima Kasih}

Ucapan terima kasih penulis berikan kepada pihak Fakultas Ilmu Komunikasi Universitas Tarumanagara yang telah mempublikasikan karya tulisan ini. Kemudian juga kepada rekan-rekan di Fakultas Ilmu Komunikasi Untar yang telah membantu memberikan masukan bagi penulis.

\section{Daftar Pustaka}

Adam, Asvi Warman. (Februari 18, 2011). Tengoklah Sejarah Ahmadiyah. Diakses pada 24 Februari 2016. http://ahmadiyah.org/tengoklah-sejarahahmadiyah/

Eriyanto. (2001). Analisis Wacana: Pengantar Analisis Teks Media. Yogjakarta: Pt. LKIS Pelangi Aksara.

Gudykunts, William B., \& Kim, Young Yun. (2003). Communicating With Strangers: An Approach To Intercultural Communication. USA: Mc-Graw Hill.

Ishanuddin. (Juni 25, 2016). Tak Melakukan Kekerasan, Mengapa Ahmadiyah Dimusuhi?. Kompas Online, diakses 24 Februari 2016. http://megapolitan.kompas.com/read/2016/06/25/19470121/tak.melakukan .kekerasan.mengapa.ahmadiyah.dimusuhi.

Martin, Judith N., \& Nakayama, Thomas K. (2007). Intercultural Communication in Context, Fourth Edition. USA: Mc-Graw Hill International Edition.

Samovar, Larry A., et al. (2010). Komunikasi Lintas Budaya, edisi tujuh. Jakarta: Salemba Humanika.

Tanjung, Anggi. (2015). Representasi Orang Baik Dalam Teks Video "Anies Baswedan;s Great Speech, Mengapa Jokowi”. Jurnal Komunikasi, 7,2, hal 129-136, diakses 18 April 2018, terarsip di : https://journal.untar.ac.id/index.php/komunikasi/article/view/13/34

Wadrianto. (Februari 6, 2011). Seribuan Warga Cikeusik Serang Jemaah Ahmadiyah. Kompas Online, diakses 24 Februari 2016. http://regional.kompas.com/read/2011/02/06/13041680/Seribuan.Warga.Ci keusik.Serang.Jemaah.Ahmadiyah 